\title{
ENVIRONMENTAL IMPACTS OF INTER-BASIN WATER TRANSFER ON WATER QUALITY IN THE JUNDIAÍ-MIRIM RIVER, SOUTH-EAST BRAZIL
}

\author{
FERNANDO HENRIQUE MACHADO ${ }^{1}$, ERIK SARTORI JEUNON GONTIJO ${ }^{1}$, \\ FREDERICO GUILHERME DE SOUZA BEGHELLI ${ }^{1}$, FELIPE HASHIMOTO FENGLER ${ }^{1}$, \\ GERSON ARAUJO DE MEDEIROS ${ }^{1}$, AFONSO PECHE FILHO ${ }^{2}$, JENER FERNANDO LEITE DE MORAES ${ }^{2}$, \\ REGINA MARCIA LONGO ${ }^{3} \&$ ADMILSON IRIO RIBEIRO $^{1}$ \\ ${ }^{1}$ São Paulo State University (Unesp), Institute of Science and Technology, Sorocaba, Brazil \\ ${ }^{2}$ Instituto Agronômico (IAC), Jundiaí, Brazil \\ ${ }^{3}$ Pontifícia Universidade Católica de Campinas (PUCCAMP), Campinas, Brazil
}

\begin{abstract}
Large-scale water transfer projects can be an important way of mitigating water scarcity and have been adopted worldwide. Nevertheless, investments in massive infrastructure, negative environmental impacts and restrictive legislation have required water managers to adopt new approaches, such as small-scale inter-basin water transfer (SSIWT), especially in industrial and urbanized regions. However, there is a lack of research concerning environmental impact assessments of SSIWT to support decisionmaking, notably in developing countries (such as Brazil). The main goal of this research was to assess the environmental impacts of water transfer on the quality of surface water in the Jundiaí-Mirim river basin, south-east Brazil. Water samples were collected along the Jundiaí-Mirim River in September 2013 (in the absence of SSIWT) and in September 2014 (during SSIWT) for determining the following parameters: $\mathrm{pH}$, temperature, turbidity, electrical conductivity (EC), dissolved oxygen (DO), total organic carbon (TOC), dissolved organic carbon (DOC), total phosphorus (TP), total nitrogen (TN), chloride $\left(\mathrm{Cl}^{-}\right)$, chlorophyll-a (Chl- $a$ ) and dissolved and total metals (Al, $\mathrm{Cd}, \mathrm{Cu}, \mathrm{Fe}, \mathrm{Mg}$ and $\mathrm{Mn}$ ). Descriptive statistics and the paired Student's $t$-test $(p<0.05)$ were used to test the hypothesis that there was an effect of SSIWT on water quality. The results showed impacts due to the transfer of ions from the Atibaia River to the Jundiaí-Mirim River, as well as the degradation of riverbanks, which significantly $(p<0.05)$ influenced DO, TOC, DOC, TN, $\mathrm{Cl}^{-}, \mathrm{Al}, \mathrm{Fe}$ and $\mathrm{Mg}$ concentrations. A positive impact on the trophic state was observed due to the increased flow caused by the water transfer, which acted to flush the river and reservoir. The findings provide important information on the environmental performance of small-scale hydraulic operations, which should assist decision-makers in establishing strategies to reduce negative environmental impacts.
\end{abstract}

Keywords: environmental management, eutrophication, Metals, water resources

\section{INTRODUCTION}

Growth and changes in the geographical distribution of the population, together with the process of industrialization and the expansion of irrigated agriculture, have led to water shortages in various regions of the planet, weakening ecosystems and increasing their vulnerability to climate change. An option used by water resource managers to address this problem has been the construction of large-scale inter-basin water transfer and reservoir systems, as has occurred in China, the United States, Brazil, Canada, Pakistan, the Soviet Union, Iran, India and South Africa, among other locations ([1-4]).

Although it is a globally well-known solution, large-scale transbasin projects have been the subject of debates and conflicts in the management of water resources, involving complex solutions because water transfer can cause loss and damage in both donor and receptor basins (Yevjevich [5]). 
Zhuang [1] described several positive and negative environmental impacts due to largescale inter-basin water transfer between donor and receptor basins in different countries. The following positive effects were identified in the receptor basin: restoration of the damaged ecological system, improvement of biological diversity, relief of ground subsidence caused by over-exploitation of groundwater and improvement of water quality. Negative impacts in the receptor basin were stimulation of water consumption and the spread of new pollution and diseases. The main negative impacts reported in the donor basin were decreased runoff volume, salinization of soil and saltwater intrusion at the estuary.

In Brazil, in the 1960s, one of the world's largest systems of interconnected reservoirs was installed in the Piracicaba, Capivari and Jundiaí river basins (collectively known as the PCJ), called the Cantareira system (Coutinho et al. [2]). This system has supplied the water needs of the São Paulo metropolitan area (SPMA), although regional conflicts have emerged due to water shortages in the PCJ caused by the expansion of industrial and urban areas, with associated increases in water demand and pollution ([6-10]).

Large-scale inter-basin water transfer has been increasingly questioned by society. Negative long-term environmental impacts have been observed on the hydrological cycle (Emanuel et al. [11], Bonacci \& Andric [12]) and on the ecological environments of rivers, lakes and reservoirs $([1,4,13-15])$, and there have been other long-term political, economic and social impacts, as in the case of Cantareira system (Gohari et al. [3], Emanuel et al. [11]). As a result, large-scale inter-basin water transfer has become a questionable option (Gleick [16]).

The use of smaller decentralized strategies, such as small-scale inter-basin water transfer (SSIWT), has been proposed to complement the installed large-scale infrastructure [16]. However, although implementation of this type of project has increased in urbanized and industrialized regions, SSIWT has been overlooked by scientists and managers, particularly in subtropical regions, so little is known or reported about its environmental impacts on water resources.

The main goal of this research was to assess the environmental impacts of small-scale inter-basin water transfer from the Atibaia River on the water quality of the Jundiaí-Mirim River, south-east Brazil.

\section{METHODOLOGY}

\subsection{Jundiaí-Mirim river basin}

The Jundiaí-Mirim river basin is located in the PCJ (Fig. 1) and supplies $95 \%$ of the drinking water consumed by Jundiaí city. This river basin has a total area of $118 \mathrm{~km}^{2}$, spanning three municipalities in São Paulo state: Jundiaí (55\% of the total area), Jarinu (36.6\%) and Campo Limpo Paulista (8.4\%) (Fengler et al. [17]). Together, these municipalities possess a population of 505,000 inhabitants, of whom 80\% live in Jundiaí city ([18]). Different classes of land use and occupation are found in the basin, with the presence of allotments, urbanization, mining and farming activities $([17,19,20])$.

The first water extraction facilities in the basin date from 1950s. In the early 1960s, there was already the need for SSIWT from the Atibaia River to the Jundiaí-Mirim River in order to normalize the streamflow during the dry season. The SSIWT currently averages $800 \mathrm{~L} \mathrm{~s}^{-1}$, which is equivalent to more than twice the natural flow of the Jundiaí-Mirim River, whose average flow is $350 \mathrm{~L} \mathrm{~s}^{-1}$. It should be highlighted that the Atibaia River is one of the main water sources in the PCJ, being responsible for the supply of 11 municipalities with a total population of around two million ([18]). 
2.2 Physical, chemical and biological water quality parameters

Monitoring was performed at five sites along the Jundiaí-Mirim River (Fig. 1) on two different dates: 2 September 2013 (during a period with no inter-basin water transfer), and 24 September 2014 (when SSIWT occurred).

During the 15 days preceding the first collection, there was only one rainfall record, of 3.4 mm on 27 August 2013, while for the second collection, there was also only one record, of $7.0 \mathrm{~mm}$ on 20 September 2014. No sample was collected at site P1 in 2013, because this was the site receiving the water transferred from the Atibaia River, which did not occur during that period.

Subsurface water samples were collected for analysis of the following parameters, using the methodologies established by Rice and Bridgewater [21]: $\mathrm{pH}$ and temperature (Temp.) (Instrutherm PH-1900 pH meter); dissolved oxygen (DO) (Digimed DM-4 oximeter); electrical conductivity (EC) (Hanna HI98304 DiST 4 EC Tester); turbidity (Turb.) (Quimis Q279P turbidity meter); chloride $\left(\mathrm{Cl}^{-}\right)$(titration using silver nitrate); total organic carbon (TOC) and dissolved organic carbon (DOC) (Analytik Jenner Multi N/C 3100 analyzer); total nitrogen (TN) and total phosphorus (TP) (Hach DR3900 Vis benchtop spectrophotometer); chlorophyll-a (Chl-a) (Micronal AJX-1900 spectrophotometer); total (TM) and dissolved (DM) metals (Al, Cd, Cu, Fe, Mg, Mn) (Agilent Technologies 700 inductively coupled plasma optical emission spectrometer (ICP-OES)). The detection limits for the metal analyses were $25.17 \mu \mathrm{g} \mathrm{L}-1$ (Al), $0.95 \mu \mathrm{g} \mathrm{L}{ }^{-1}(\mathrm{Cd}), 0.74 \mu \mathrm{g} \mathrm{L}{ }^{-1}(\mathrm{Cu}), 2.44 \mu \mathrm{g} \mathrm{L}^{-1}(\mathrm{Fe}), 2.57 \mu \mathrm{g} \mathrm{L}-1$ (Mg), and $0.31 \mu \mathrm{g} \mathrm{L}-1(\mathrm{Mn})$.

The results were compared to the limit values established in Brazilian resolution 357/2005 ([22]) for the water quality of Class 1 rivers (such as the Jundiaí-Mirim River). These criteria apply to rivers used for human supply (after conventional treatment), the protection of aquatic communities, primary contact recreation (such as swimming, skiing, and diving) and horticultural irrigation.

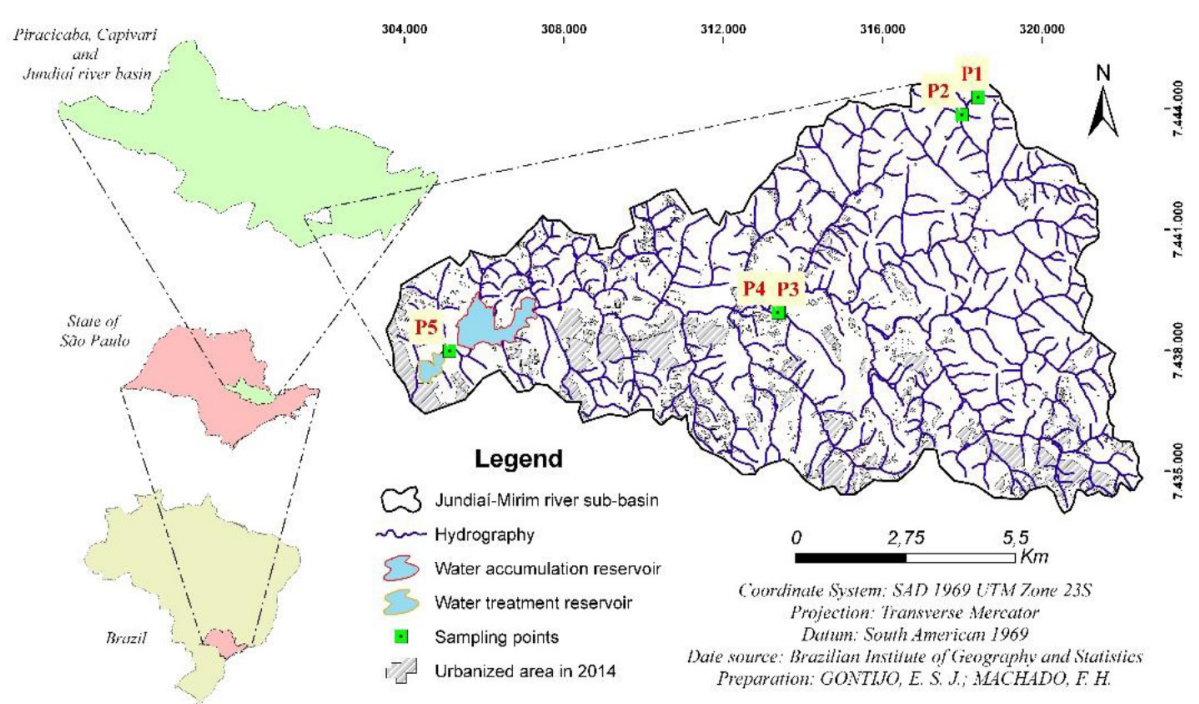

Figure 1: Location of sampling sites in the Jundiaí-Mirim river basin, São Paulo State, Brazil. 
The trophic state index (TSI) was estimated by the methodology proposed by Carlson [23] and modified by Cunha et al. [24] for tropical and subtropical environments.

The one sample Student's $t$-test ( $p<0.05,4$ degrees of freedom) was used to determining the existing differences among two populations that can be paired, since the observations are the same type of measurements, as water quality parameters, on the same site at two different time (in the period with no inter-basin water transfer and when SSIWT occurred) (Ostle and Malone [25]).

\section{RESULTS AND DISCUSSION}

\subsection{Limnological and chlorophyll- $a$ water quality parameters}

Table 1 presents the results of the water quality analyses and the TSI values for the Jundiaí-Mirim River. The SSIWT reduced the average $\mathrm{pH}$ of the Jundiaí-Mirim River by $4.6 \%$, although in both periods the variation of $\mathrm{pH}$ was in the range observed previously for streams in the PCJ (Medeiros et al. [7], and Martinelli et al. [8]) and that recommended by [22]. At the other sites sampled during SSIWT, the $\mathrm{pH}$ was found to increase downstream (from P2 to P5), probably due to the mixing of the Atibaia and Jundiaí-Mirim waters.

The dissolved oxygen concentrations exceeded the recommended lower limit of $6.0 \mathrm{mg} \mathrm{L}^{-1}$ ([22]) in most cases, irrespective of inter-basin water transfer. The only exception was site P5 (sample P5-N), located downstream of the reservoir, indicating an influence of water shortage during the period without SSIWT. Previous investigations of water quality in streams of the PCJ have found average DO concentrations lower than $3.0 \mathrm{mg} \mathrm{L}^{-1}$ in urbanized microbasins $([7,9,10])$, while the values for rural catchments were higher than $7.0 \mathrm{mg} \mathrm{L}^{-1}$ ([9, 10]). On average, the DO concentration increased by $6.4 \%$ with SSIWT, which could be attributed to greater mixing of water in the Jundiaí-Mirim River, as observed visually during the sample collections. The water temperature showed a difference of $1{ }^{\circ} \mathrm{C}(5.1 \%)$ between the two measurements periods, following the average air temperature, with values of $21.7 \mathrm{oC}$ in 2013 (without SSIWT) and $22.80 \mathrm{C}$ in 2014 (with SSIWT).

The electrical conductivity can be used as a proxy for the ion content of the water in studies of anthropogenic impacts in streams ([9]). The average EC increased by $125 \%$ with SSIWT, evidencing the impact of ions introduced in water from the Atibaia River, where the highest EC was observed $\left(115 \mu \mathrm{S} \mathrm{cm}^{-1}\right.$ at $\left.\mathrm{P} 1-\mathrm{Y}\right)$. Therefore, comparison of the two sampling periods showed that SSIWT caused changes in EC downstream. In 2013, EC increased by $50 \%$ from the rural $(\mathrm{P} 2-\mathrm{N})$ to the urbanized area $(\mathrm{P} 5-\mathrm{N})$, highlighting the effect of soil use and occupation. However, in 2014 EC decreased by $15.6 \%$ from the rural area (P1-Y) to the urbanized area (P5-Y).

Daniel et al. [9] analysed ten streams corresponding to rural and urbanized areas in the PCJ. In streams with heavy urbanization in their catchments and without sewage treatment, average EC ranged from $131 \mu \mathrm{S} \mathrm{cm}^{-1}$ to $598 \mu \mathrm{S} \mathrm{cm}^{-1}$, while in rural catchments with almost no urbanization or with sewage treatment, average EC varied from $53 \mu \mathrm{S} \mathrm{cm}^{-1}$ to $159 \mu \mathrm{S} \mathrm{cm}^{-1}$ ([9]). Ometo et al. [10] found similar values for streams of the PCJ river basin, with EC ranging from $55.5 \mu \mathrm{S} \mathrm{cm}^{-1}$ in the rural region to $271.8 \mu \mathrm{S} \mathrm{cm}^{-1}$ under urban influence. Therefore, the results for average EC indicated that the water quality of the Jundiaí-Mirim River was similar to regional values for rural areas, independent of SSIWT.

SSIWT raised the average turbidity by $219 \%$, reflecting the cumulative effect of the increased flow along the Jundiaí-Mirim River, despite the lower turbidity observed in the 


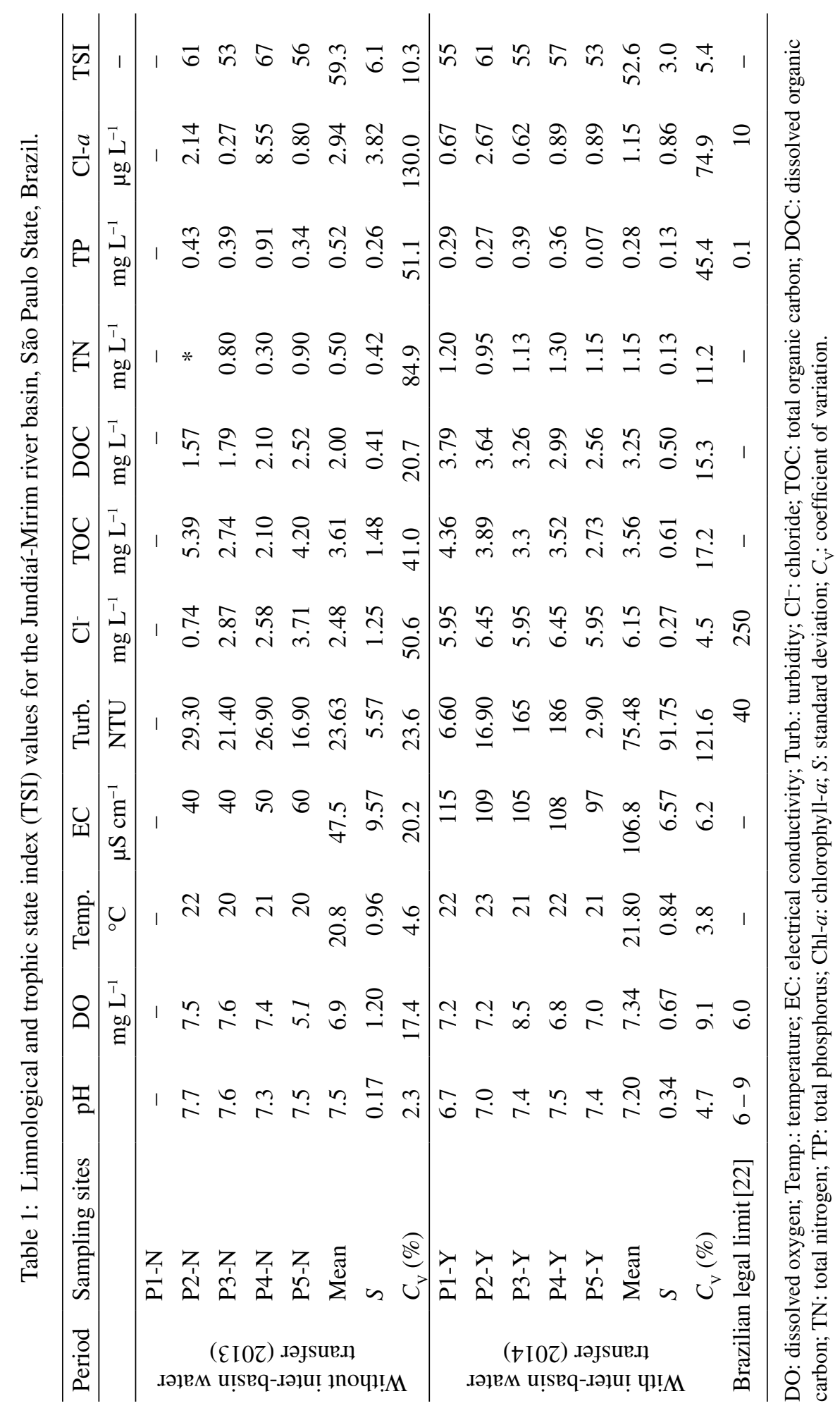


water transferred from the Atibaia River (6.6 UNT). During SSIWT, there was an increase in around 1,400\% from P1-Y to P4-Y, during the SSIWT, where Medeiros et al. [20] reported undermining of the margins. From P4-Y to P5-Y, the turbidity decreased by $98.4 \%$, because the reservoir behaved as a sediment decanter.

Urbanization has been associated with increased salinity of surface water, due to higher concentrations of ions such as chloride $\left(\mathrm{Cl}^{-}\right)([26,27])$. Sewage effluent and treated wastewater from metropolitan areas are major sources of $\mathrm{Cl}^{-}$in surface waters, where its concentration can exceed $200 \mathrm{mg} \mathrm{L}^{-1}([10,27,28])$. Therefore, $\mathrm{Cl}^{-}$can be used as a marker for the migration of effluents in groundwater and as an indicator of sewage in aquatic systems $([29,30])$.

SSIWT increased the concentration of chloride by $148 \%$, on average, and changed its upstream-downstream profile. In 2013 (without SSIWT), $\mathrm{Cl}^{-}$increased by $250 \%$ from rural (P2-N) to urbanized (P5-N) areas, indicative of anthropogenic influence that was probably due to the release of sewage, synthetic fertilizers and/or livestock waste ([28]). On the other hand, in 2014 (with SSIWT), the $\mathrm{Cl}^{-}$concentration only varied from 5.95 to $6.45 \mathrm{mg} \mathrm{L}^{-1}$ and there was no relation with land use. Comparison of these results with previous findings for the PCJ ([10]) strongly indicated that human sewage was a source of $\mathrm{Cl}^{-}$in the urbanized catchments. Martinelli et al. [8] reported an average $\mathrm{Cl}^{-}$concentration of $3.65 \mathrm{mg} \mathrm{L}^{-1}$ for the Atibaia and Jaguari Rivers in less polluted regions of the PCJ. Therefore, based on regional $\mathrm{Cl}^{-}$values, it can be inferred that SSIWT changed the water quality of the Jundiaí-Mirim River, although the concentrations were lower than $200 \mathrm{mg} \mathrm{L}^{-1}$, the threshold at which effects begin to be observed in the biota (Kelly et al. [28]).

Total organic carbon represents a useful indicator of the pollution level in a water body, since wastewaters and effluents such as pig slurry have high TOC contents (Bolado-Rodrigues et al. [31]). SSIWT reduced the average TOC concentration by $1.4 \%$, with distinct trends for this parameter in the two periods. In 2013, the highest TOC concentration was at site P2-N (5.39 $\left.\mathrm{mg} \mathrm{L}^{-1}\right)$, which could have been due to nearby agricultural activities, while in 2014 the highest observed TOC concentration was in water from the Atibaia River (4.36 $\left.\mathrm{mg} \mathrm{L}^{-1}\right)$.

Dissolved organic carbon is a parameter that has been used to evaluate the environmental impact of sewage discharges on surface water quality in the PCJ ([8-10]). SSIWT caused an increase of $63 \%$ in the concentration of DOC, indicating the influence of Atibaia water. Moreover, the DOC concentration trends in the Jundiaí-Mirim River differed for the two periods. In 2013 (without SSIWT), DOC followed the same trend as $\mathrm{Cl}^{-}$and $\mathrm{EC}$, increasing by $61 \%$ from P1-N to P5-N. However, in 2014 (with SSIWT), the Atibaia water presented the highest DOC, with concentrations decreasing by $32.5 \%$ downstream, from P1-Y to P5-Y. Ometo et al. [10] measured average DOC values in the ranges $2.6-3.0 \mathrm{mg} \mathrm{L}^{-1}$ and $5.1-10.5$ $\mathrm{mg} \mathrm{L}^{-1}$ in streams of rural and urbanized catchments, respectively, as also observed in the PCJ ([8-9]). Therefore, the range of DOC concentrations observed in the Jundiaí-Mirim River corresponded to that found in less impacted headwater or unpolluted regions of the PCJ basin, for both periods.

Nitrogen and phosphorus are primary nutrients implicated in the eutrophication of natural water bodies and reservoirs. High concentrations of these nutrients can be caused by diffuse pollution from crop lands, as well as point source pollution from industrial effluents or urban sewage discharges (Medeiros et al. [7], Ometo et al. [10]). In the present case, there was a significant increase of $129 \%$ in the average total nitrogen concentration during SSIWT, and once more there was evidence of its negative influence on the water quality of the Jundiaí-Mirim 
River. In contrast to the TN trend, SSIWT reduced the average total phosphorus concentration by $46.1 \%$, probably due to dilution caused by the higher flow. Despite this dilution, TP concentration exceeded the upper limit established by [22] for Class 1 rivers.

Chlorophyll- $a$ has been used as an indicator of the trophic state of aquatic environments $([13,24,32])$. Considering this parameter in isolation, SSIWT had a positive effect because it reduced the average $\mathrm{Cl}-a$ concentration by $61 \%$, which could be attributed to the increased flow and consequently a shorter nutrient retention time. Other studies have found that flushing events can be useful for preventing and/or controlling eutrophication and pollution in reservoirs $([15,33])$.

The trophic state index (TSI) values were calculated based on the results for TP and Cl- $a$. Out of the total of nine water samples obtained with and without SSIWT, six $(67 \%)$ were classified as mesotrophic $(52<\mathrm{TSI} \leq 59)$, two $(22 \%)$ as eutrophic $(59<\mathrm{TSI} \leq 63)$ and one $(11 \%)$ at the maximum limit of the hypereutrophic class $(63<\mathrm{TSI} \leq 67)$. Therefore, no water sample was classified as oligotrophic $(47<$ TSI $\leq 52)$ or ultraoligotrophic (TSI $\leq 47)$. Sites $\mathrm{P} 2$ and $\mathrm{P} 4$, corresponding to lentic environments, presented the highest levels of hypertrophy. Site P4 could be highlighted, since in the absence of SSIWT the TSI reached 67, the upper hypereutrophic limit, while the value decreased to 57 during SSIWT, demonstrating a positive environmental impact of water transfer.

\subsection{Metal analysis}

Table 2 shows the total and dissolved metals concentrations for 2013 (without SSIWT) and 2014 (with SSIWT).

On average, SSIWT increased the concentration of total and dissolved Al by 2,370\% and $1,216 \%$, respectively. Dissolved Al exceeded the limit established for Class 1 rivers (100 $\mu \mathrm{g}$ $\mathrm{L}^{-1}$ ) according to CONAMA resolution 357/05. The concentration of dissolved $\mathrm{Al}$ in surface waters varies greatly, because it depends on physical, chemical and geological factors. At $\mathrm{pH}$ around 7, concentrations range from 1 to $50 \mu \mathrm{g} \mathrm{\textrm {L } ^ { - 1 }}$ ([34]). Sources of contamination by aluminium include discharges of domestic wastewater and industrial effluents (from the manufacture of pharmaceuticals and metal products), and this element is also present in the composition of some agrochemicals ([35]).

Based on the total Al results, two possible factors could contribute to explaining the difference between the two periods. The first was related to the high concentration of total Al that was introduced during water transfer from the Atibaia River. The second was related to the increased flow, which caused undermining of the margins and re-suspension of sediment. The tropical soil of the Jundiaí-Mirim river basin has a high concentration of this metal, which contributed to increasing the concentration of total Al between sites P1 and P4 during SSIWT by $1,076 \%$. Total Al decreased by $89.8 \%$ between sites P4 and P5, after the Jundiaí reservoir, probably due to the decantation of sediment in the reservoir.

The behaviour of $\mathrm{Fe}$ was similar to that of $\mathrm{Al}$, with inputs of this metal from the Atibaia River during SSIWT. Higher Fe concentrations were observed at sites P3 and P4, possibly due to anthropic influence (degradation of the river, soils and riparian forest), which contributed to transporting sediments to the river, as observed previously ([20]).

Most of the total $\mathrm{Fe}$ was deposited in the reservoir, probably in the particulate fraction $(>0.45 \mu \mathrm{m})$, which explained the lower levels of total Fe at site P5. The dissolved Fe concentration was higher than $300 \mu \mathrm{g} \mathrm{L}^{-1}$ during SSIWT, hence exceeding the limit value for Class 1 rivers established in Brazilian legislation ([22]). 


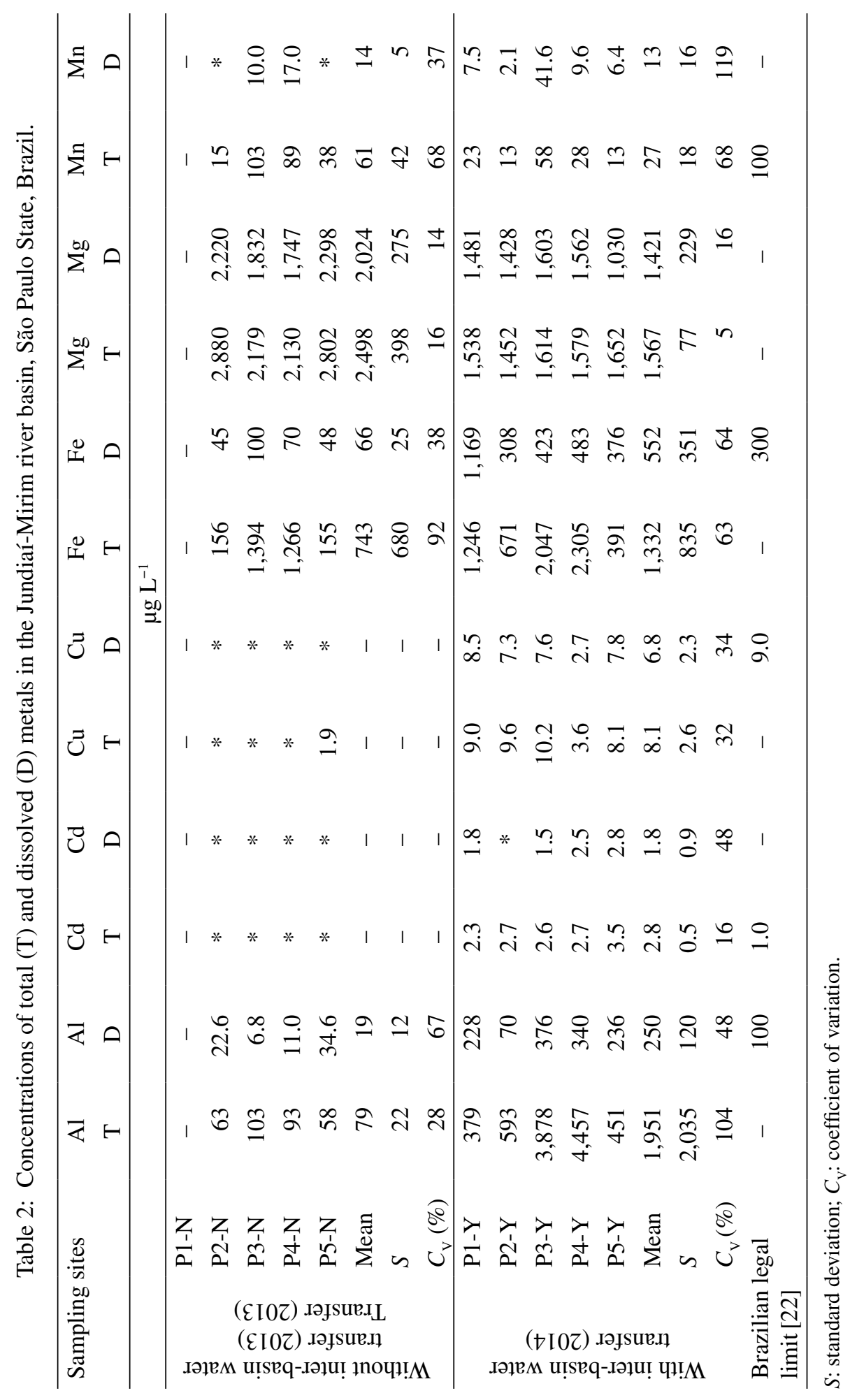


Considering the period with SSIWT, there were concentrations above the established limits ([22]) for the following metals: dissolved Al (samples P1-Y, P3-Y, P4-Y, and P5-Y); total Cd (all samples) and dissolved Fe (all samples). The increased flow during the SSIWT period probably caused the re-suspension of some metals from sediments, explaining the higher concentrations of $\mathrm{Cd}$ and $\mathrm{Cu}$.

Consequently, the concentrations of $\mathrm{Cd}$ at several sites during SSIWT surpassed the limits for Class 1 rivers (total $\mathrm{Cd}<1.0 \mu \mathrm{g} \mathrm{\textrm {L } ^ { - 1 }}$ ). These results were in agreement with previous studies of rivers and reservoirs in urbanized areas of the PCJ (Medeiros et al. [6], Moreira \& Fazza [36]).

In contrast, the concentration of $\mathrm{Mg}$ decreased during SSIWT, probably because Atibaia River water contained lower concentrations of this metal, which caused a dilution effect.

The concentrations of $\mathrm{Mn}$ along the river were in the range $15-103 \mu \mathrm{g} \mathrm{L^{-1 }}$ for the samples obtained in both 2013 and 2014, with higher values in 2013. However, the levels were in compliance with the limit for Class 1 rivers established in Brazilian legislation $\left(<100 \mu \mathrm{g} \mathrm{L}{ }^{-1}\right)$ [22].

\subsection{Statistical analysis}

The results of the statistical analyses confirmed the significant impact of SSIWT on the water quality of the Jundiaí-Mirim River. Considering the limnological variables (Table 1), there was a significant influence on DO, $\mathrm{Cl}^{-}, \mathrm{EC}, \mathrm{TOC}$ and DOC (paired Student's $t$-test, $p<0.05$ ). A positive environmental impact was observed for $\mathrm{DO}$, while negative impacts were associated with higher $\mathrm{Cl}^{-}, \mathrm{EC}, \mathrm{TOC}, \mathrm{DOC}$ and TN concentrations. There was no significant effect of SSIWT on TSI, probably due to the lower levels of phosphorus, which has an important influence on the trophic state ([13]).

The one sample Student's t-test was only performed for $\mathrm{Al}, \mathrm{Fe}$ and $\mathrm{Mg}$, because all the values found for these metals were higher than the detection limits (for both periods). The results corroborated the descriptive statistics, with a significant influence of SSIWT $(p<0.05)$ on the concentrations of all the metals analysed, including both dissolved and total fractions.

\section{CONCLUSIONS}

The environmental impact assessment revealed negative and positive effects of SSIWT on the chemical water quality of the Jundiaí-Mirim River. Negative environmental impacts could be attributed to the introduction of ions from the Atibaia River water, while the erosion of banks and the resuspension of sediment resulted in higher concentrations of some metals. Positive environmental impacts observed during SSIWT were a reduction of eutrophication and increase of dissolved oxygen, due to the higher flow.

The results indicated a need for the development and implementation of public policies designed to protect this basin, especially considering the population growth in the region. These policies should be based on the establishment of goals and objectives capable of delivering improvements in the quality and quantity of water in order to meet long-term intended uses.

\section{ACKNOWLEDGMENTS}

The authors thank CAPES and FAPESP (12/17727-8 and 13/03494-4), Agronomic Institute (CEA/IAC) for the support in the field work and the Laboratório Multiusuário de Análise e Caracterização de Amostras (LMACA II). The authors also thank Dr Andrew George Allen, who provided a very helpful contribution during the review process. 


\section{REFERENCES}

[1] Zhuang, W., Eco-environmental impact of inter-basin water transfer projects: A review. Environmental Science and Pollution Research, 23, pp. 12867-12879, 2016. DOI: 10.1007/ s11356-016-6854-3.

[2] Coutinho, R.M., Kraenkel, R.A. \& Prado, P.I., Catastrophic regime shift in water reservoirs and São Paulo water supply crisis. PLoS ONE, 10(9), pp. 1-14, 2015. DOI: 10.1371/ journal.pone.0138278.t001.

[3] Gohari, A., Eslamian, S., Mirchi, A., Abedi-Koupaei, J., Bavani, A.M. \& Madani, K., Water transfer as a solution to water shortage: A fix that can backfire. Journal of Hydrology, 491, pp. 23-39, 2013, available at http://dx.doi.org/10.1016/j.jhydrol.2013.03.021 (accessed 15 January 2017).

[4] Kadye, W.T. \& Booth, A.J., An invader within an altered landscape: One catfish, two rivers and an inter-basin water transfer scheme. River Research and Applications, 29, pp. 1131-1146, 2013, available at http://dx.doi.org/10.1002/rra.2599 (accessed 15 January 2017).

[5] Yevjevich, V., Water diversions and interbasin transfers. Water International, 26(3), pp. 342-348, 2001, available at http://dx.doi.org/10.1080/02508060108686926 (accessed 30 January 2017).

[6] Medeiros, G.A. et al., Evaluation of metals in water and sediments of micro-basins in the city of Americana, São Paulo state, Brazil. WIT Transactions on Ecology and the Environment, Vol. 172, WIT Press: Southampton and Boston, MA, pp. 201-212, 2013, available at http://dx.doi.org/10.2495/RBM130171 (accessed 15 January 2017).

[7] Medeiros, G.A., Archanjo, P., Simionato, R. \& Reis, F.A.G.V., Diagnosis of the water quality of the Recanto Creek microbasin, at Americana, in the state of Sao Paulo, Brazil. Geociências, 28(2), pp. 181-191, 2009 (in Portuguese).

[8] Martinelli, L.A., et al., Effects of sewage on the chemical composition of Piracicaba River, Brazil. Water Air and Soil Pollution, 110(1-2), pp. 67-79, 1999, available at http://dx.doi.org/10.1023/A:1005052213652 (accessed 15 January 2017).

[9] Daniel, M.H.B., et al., Effects of urban sewage on dissolved oxygen, dissolved inorganic and organic carbon, and electrical conductivity of small streams along a gradient of urbanization in the Piracicaba River basin. Water, Air and Soil Pollution, 136(1-4), pp. 189-206, 2002. DOI: 10.1023/A:1015287708170.

[10] Ometo, J.P.H.B., et al., Effects of land use on water chemistry and macroinvertebrates in two streams of the Piracicaba river basin, south-east Brazil. Freshwater Biology, 44(2), pp. 327-337, 2000, available at http://dx.doi.org/10.1046/j.1365-2427.2000.00557.x (accessed 15 January 2017).

[11] Emanuel, R.E., Buckley, J.J., Caldwell, P.V., McNulty, S.G. \& Sun, G., Influence of basin characteristics on the effectiveness and downstream reach of interbasin water transfers: Displacing a problem. Environmental Research Letter, 10, pp. 1-9, 2015, available at http://dx.doi.org/10.1088/1748-9326/10/12/124005 (accessed 30 January 2017).

[12] Bonacci, O. \& Andric, I., Impact of an inter-basin water transfer and reservoir operation on a karst open streamflow hydrological regime: an example from the Dinaric karst (Croatia). Hydrological Processes, 24, pp. 3852-3863, 2010, available at http://dx.doi. org/10.1002/hyp.7817 (accessed 30 January 2017).

[13] Zeng, Q., Qin, L. \& Li, X., The potential impact of an inter-basin water transfer project on nutrients (nitrogen and phosphorous) and chlorophyll a of the receiving water system. Science of the Total Environment, 536, pp. 675-686, 2015, available at http:// dx.doi.org/10.1016/j.scitotenv.2015.07.042 (accessed 30 January 2017). 
[14] Fornarelli, R., Antenucci, J.P. \& Marti, C.L., Disturbance, diversity and phytoplankton production in a reservoir affected by inter-basin water transfers. Hydrobiologia, 705, pp. 9-26, 2013. DOI: 10.1007/s10750-012-1351-2.

[15] Li, Y., et al., Assessing and modeling impacts of different inter-basin water transfer routes on Lake Taihu and the Yangtze River, China. Ecological Engineering, 60, 399-413, 2013, available at http://dx.doi.org/10.1016/j.ecoleng.2013.09.067 (accessed 30 January 2017).

[16] Gleick, P.H., Global freshwater resources: Soft-path solutions for the 21 st century. Science, 302, pp. 1524-1528, 2003, available at http://dx.doi.org/10.1126/science. 1089967 (accessed 20 January 2017).

[17] Fengler, F.H., et al., Environmental quality of forest fragments in Jundiaí-Mirim river basin between 1972 and 2013. Revista Brasileira de Engenharia Agrícola e Ambiental, 19, pp. 402-408, 2015 (in Portuguese). DOI: 10.1590/1807-1929/agriambi.v19n4p402-408.

[18] Brazilian Institute of Geography and Statistics (IBGE). Cidades@: Resource Document, Brasilia DF, available at http://www.cidades.ibge.gov.br/ (accessed 24 January 2017) (in Portuguese).

[19] Freitas, E.P., Moraes, J.F.L., Peche Filho, A. \& Storino, M., Environmental indicators for areas of permanent preservation. Revista Brasileira de Engenharia Agrícola e Ambiental, 17, pp. 443-449, 2013 (in Portuguese). DOI: 10.1590/S1415-43662013000400013.

[20] Medeiros, G.A., et al., Environmental assessment using landscape analysis methodology: The case of the Jundiaí Mirim river basin, Southeast Brazil. WIT Transactions on Ecology and the Environment, Vol. 203, WIT Press: Southampton and Boston, MA, pp. 25-36, 2016, available at http://dx.doi.org/10.2495/EID160031 (accessed 30 January 2017).

[21] Rice, E.W. \& Bridgewater, L. (eds.), Standard Methods for the Examination of Water and Wastewater, American Public Health Association, APHA Press: Washington, DC, 2012.

[22] National Environment Council (CONAMA), Resolution no 35717 Mar. 2005. Resolution 357/2005. Environmental Guidelines for Water Resources and Standards for the Release of Effluents, DOU: Brasília DF, 2005 (in Portuguese).

[23] Carlson, R.E., A trophic state index for lakes. Limnology and Ocenagraphy, 22(2), pp. 361-369, 1977.

[24] Cunha, D.G.F., Calijuri, M.D. \& Lamparelli, M.C., A trophic state index for tropical/ subtropical reservoirs (TSItsr). Ecological Engineering, 60, pp. 126-134, 2013, available at http://dx.doi.org/10.1016/j.ecoleng.2013.07.058 (accessed 20 January 2017).

[25] Ostle, B. \& Malone, L.C., Statistics in Research. Iowa State University Press: Ames, 1988.

[26] Steele, M.K. \& Aitkenhead-Peterson, J.A., Long-term sodium and chloride surface water exports from the Dallas/Fort Worth region. Science of the Total Environment, 409, pp. 3021-3032, 2011, available at http://dx.doi.org/10.1016/j.scitotenv.2011.04.015 (accessed 30 January 2017).

[27] Rose, S., The effects of urbanization on the hydrochemistry of base flow within the Chattahoochee River Basin (Georgia, USA). Journal of Hydrology, 341, pp. 42-54, 2007, available at http://dx.doi.org/10.1016/j.jhydrol.2007.04.019 (accessed 30 January 2017).

[28] Kelly, W.R., Panno, S.V., Hackley, K.C., Hwang, H.H., Martinsek, A.T. \& Markus, M., Using chloride and other ions to trace sewage and road salt in the Illinois Waterway. Applied Geochemistry, 25, pp. 661-673, 2010, available at http://dx.doi.org/10.1016/j. apgeochem.2010.01.020 (accessed 30 January 2017).

[29] Vengosh, A. \& Pankratov, I., Chloride/bromide and chloride/fluoride ratios of domestic sewage effluents and associated contaminated ground water. Ground Water, 36(5), 
pp. 815-824, 1998, available at http://dx.doi.org/10.1111/j.1745-6584.1998.tb02200.x (accessed 30 January 2017).

[30] Haiao, Z. \& Jinglu, W., Tracing the nitrate sources of the Yili River in the Taihu Lake Watershed: A dual isotope approach. Water, 7(1), pp. 188-201, 2014. DOI: 10.3390/ w7010188.

[31] Bolado-Rodríguez, S., García-Sinovas, D. \& Álvarez-Benedí, J., Application of pig slurry to soils: Effect of air stripping treatment on nitrogen and TOC leaching. Journal of Environmental Management, 91, pp. 2594-2598, 2010, available at http://dx.doi. org/10.1016/j.jenvman.2010.07.020 (accessed 30 January 2017).

[32] Beghelli, F.G.S., et al., Uso do índice de estado trófico e análise rápida da comunidade de macroinvertebrados como indicadores da qualidade ambiental das águas na Bacia do Rio Jundiaí-Mirim - SP - BR. Brazilian Journal of Aquatic Science and Technology, 19(1), pp. 13-22, 2015 (in Portuguese). DOI: 10.14210/bjast.v19n1.p13-22.

[33] Padovesi-Fosneca, C., Philomeno M.G. \& Andreoni-Batista, C., Limnological features after a flushing event in Paranoá Reservoir, central Brazil. Acta Limnologica Brasiliensia, 21(3), pp. 277-285, 2009.

[34] World Health Organization (WHO), Aluminium. Environmental Health Criteria 194. WHO: Geneva, 1997.

[35] Yokel, R.A. \& McNamara, P.J., Aluminium toxicokinetics: An updated minireview. Pharmacolgy \& Toxicology, 88, pp. 159-167, 2001, available at http://dx.doi.org/10. 1034/j.1600-0773.2001.d01-98.x (accessed 30 January 2017).

[36] Moreira, S. \& Fazza, E.V., Serra streams in the city of Limeira (SP-Brazil) by Synchrotron Radiation Total Reflection X-ray Fluorescence. Spectrochimica Acta, 63(12), pp. 1432-1442, 2008, available at http://dx.doi.org/10.1016/j.sab.2008.10.022 (accessed 30 January 2017). 